\title{
Sociology of the Transcendental Delirium World ${ }^{\star}$
}

\author{
ALEKSANDER MANTERYS** \\ Institute of Philosophy and Sociology, Polish Academy of Sciences, Warsaw, Poland
}

\begin{abstract}
The author analyses the individual-empire relationship in the Soviet Union. The literary work Moscow-Pietushki, by Venedikt Yerofeyev, is treated as a superb instantiation of Soviet interaction rituals. The author rejects the Homo sovieticus model, the orthodox implementation of which leads to a recognition of individuals as puppets of the system. The analysis, inspired by Goffman's and Collins' findings, shows the social mechanisms which make possible the construction of a temporary world of transcendental delirium, located on the borderline of system reality. The constitution and duration of this anti-utopia system inside society reveal the relative autonomy of Soviet social actors: their conduct within this world is conditioned mainly by the availability of alcohol and the capability to play the 'parlour game'. Such analysis, which surveys the universal logic of interaction rituals, facilitates a reasonable comparison of the practices of Soviet actors with the practices of actors located on the 'friendly' peripheries of the system, and with the relevancy systems and the actions of the CEE and the Western bourgeoisie.
\end{abstract}

Sociologický časopis/Czech Sociological Review, 2002, Vol. 38, No. 3: 297-309

\section{Introductory Remarks}

The aim of this paper is to attempt to employ interaction theory in order to characterise and explain the individual-empire relationship. By 'explanation' I mean the disclosure of mechanisms that underlie the behaviour of social actors, and the construction and maintenance of interaction orders and social structures. Taking up a tentative attempt at such an explanation, I shall here be using the concrete example of the literary work Moscow-Pietushki, by Venedikt Yerofeyev [1994] (MP hereafter), which is situated in the historical realities of the period of the duration and transformations of the Soviet empire.

I treat literary works as the products of the activities of social actors in relation to and within society. From my point of view they are social facts, just like other products and domains of social actors' activities. In this sense, persistence in the thesis that literary descriptions are fictitious is heuristically fruitless. This thesis is as equally idle or fruitless as statements about the fictitiousness of expectations that a 'full-blooded' actor will have a date with a virtual cyber-beauty or will discuss theological issues with a living St. Thomas Aquinas. I agree with Thomas J. Scheff [1997: 157ff] that, for example, the world of Shakespearean drama reveals, in an unmatched way, tensions and conflicts, and shame and

\footnotetext{
* I would like to express my gratitude to Alina Szulżycka for her help in improving the English style of this paper and to Henryk Domański, Janusz Goćkowski, Hanna Świda-Ziemba for their comments.

** Direct all correspondence to: Aleksander Manterys, Polish Academy of Sciences, Institute of Philosophy and Sociology, Nowy Świat 72 (Pałac Staszica), 00-330 Warszawa, Poland, e-mail aleksander.manterys@wp.pl
} 
anger on the manifold levels of social life: from male-female relationships to international conflicts. Literary works as documents of a certain age are well designed for sociological analysis if a sociologist is able to identify certain characteristic properties that refer to the social actors, interactions and structures in order to reconstruct, interpret and explain the relationships that connect the components of the socio-cultural universe.

The limitation of my own analysis to Moscow-Pietushki is deliberate. First, a sociologist interested in the construction of theory is not obliged to analyse all available empirical exemplifications to be able to grasp the structural properties of the phenomenon under investigation. Second, there is no obstacle to applying the analysis of the single case presented here to other 'documents' that deal with the Soviet empire, and then, homologically, in reference to other kinds of empires. Third, Moscow-Pietushki includes a condensed and perfect description of the interaction orders that are typical of Soviet reality and reveals a world of alcohol anti-utopia, a structural hole or gap within the overall architectonics of the empire, which is inexplicable on the basis of orthodox Homo sovieticus presuppositions. Fourth, this kind of analysis enables further studies comparing the habitus of the Soviet man with the habitus of the CEE bourgeois, which is typically treated as a kind of mixture of socialist and Western attributes, a simple product of transition processes or system and institutional changes in post-socialist countries.

\section{Homo sovieticus vs. Homo sociologicus}

Within the social sciences there is no lack of analyses concentrating on the phenomenon of the Soviet empire. Broad, intensive, interdisciplinary and well-financed Soviet studies provide the best evidence of this. However, what deters me from this kind of analysis is not only - as Randall Collins [1995] aptly notes - the relentless conservatism or anti-communism of sovietologists, but the principal lack of an answer to the question of the social mechanisms underlying the origin, duration or maintenance and collapse of the Soviet Union. In the best case one must deal with accounts which refer to concrete events, the specificity or exceptionality of a certain sociation form or institutional network, but without an explanation of such events through the theoretical categories of the social sciences.

However, in this flood of hyperfactualism one can still find a few islands of theory. In Theda Skocpol's analysis [1973], the Russian Revolution is treated as an actualisation of a revolutionary situation. The theoretical aspect of her analysis lies in the fact that she constructs analytical tools that can be applied not only to a single historical course of events, but also to a series of homologically unstable societies (e.g. France and China) [see also Staniszkis 1992; Tilly 1993; Wallerstein 1974, 1980, 1989]. Piotr Sztompka [1993: 301] treats revolution as an aspect of becoming a society, the most rapid and spectacular one, which evokes changes at all levels of social reality [see also Sztompka 1999: 151]. What is important here is that the actualised revolutionary situation creates a new structural arrangement of society, in the face of which social actors (individuals and collectives) elaborate new types of adaptation or at least modify current definitions of the particular components of their social settings.

In fact, the classic Durkheimian individual-society dichotomy is the metatheoretical framework of my own analysis. A human being is the user and modifier of social rituals, which manifest themselves not only through the strength of constraint or social inertia but 
also in the form of components of definitions of life situations. Here I am interested in tracing how in fact it is possible to establish relationships between the structural constraints network and actions of actors who function in the predefined world of the empire and reflexively act on external situation patterns. The dialectical aspect of the relationship is crucial. If one neglects this dialectical aspect of the relationship between the empire and the individual, one may fall into a - politically correct but heuristically impotent - Homo sovieticus trap.

The concept of Homo sovieticus, proposed by Alexander Zinoviev [1984, 1986], is an object of varied, ongoing interpretation. The Soviet man is typically recognised as the next historical manifestation of the 'Russian soul', which is an especially attractive object for global social experiments. In this sense communist totalitarianism undoubtedly has its roots in the Russian mentality. But from here it is only a small step toward recognising the genesis 'from above' and the existence of communism in Russia; that is, to conceive it as it has been imposed by the elites, as a system of the organisation of social life. It leads to the creation of the orthodox image of Homo sovieticus, that is, the social actor conceived as a puppet of the system. This actor reproduces system components and completely fulfills the expectations of communist demiurges and anti-communist sovietologists. In my opinion, what is most important in Zinoviev's argumentation is the comprehensive presentation of the ways in which communist totalitarianism has been coming to be accepted by individuals and social groups, becoming a paramount, even single reality, within and toward which any social actors' activities can proceed.

Undoubtedly, it is easy to apply the orthodox interpretation of Homo sovieticus and explain the actors' conduct through presenting the irresistible influence of the imperial constraining network as paralysing, allegedly or actually, individual autonomy. But a question arises: why do social actors choose these and not other ways of conduct? Erik Olin Wright [1997] clearly sees it a danger to believe in the omnipotence of macro-structural explanations, contending (contrary to Marx's expectations) that the same class position does not produce equal class-consciousness. On the other hand, overemphasising the constructivist picture of society, as do Herbert Blumer [1969/1986] or Norman K. Denzin [1987, 1989, 1992, 1994], is also theoretically dangerous: comprehending actors' actions as a process can lead to a difficulty in deciding why the regularities in human behaviour within the Soviet empire system definitely differ from regularities stated in the practices of the Western or CEE bourgeoisie.

In this theoretical situation a sociologist has two choices. The first choice is to escape into contextualism, that is, the recognition of the characteristics of the context of a particular action as the primary task for the social researcher. It means in fact resigning from any theoretical attempt to account for social events, if sociological theory is understood as an effort to penetrate universal principles or rules underlying the functioning of society. The second possibility implies an immersion in a concrete social reality in order to find universal properties of human interactions, and especially the ways in which the social order is achieved on this level. In reference to my aim, it deals with a specification of the ways in which it is possible to create or construct alternative realities or, more generally, to construct a certain special world, as Norbert Wiley [2000] calls it. One can speak here of a relationship between code and the interpretation of the experiences and conditions of its usage, or - as it is sometimes called - between discourse and the narrations by which a given discourse becomes a social resource and theme for social actors' activities [see Alexander 1992; 
Alexander \& Smith 1993; Calhoun 1995; Kane 1996; Rambo \& Chan 1990; Sewell 1992; Smith 1998; Sommers \& Gibson 1994]. The construction of a certain special world, to refer directly to the idea of transposability presented by William H. Sewell, Jr. and Anne E. Kane, includes, first of all, the modes of application and change of socially available forms, contents and meanings in the process of their implementation within a new domain of social activity.

\section{Rituals and Interaction Orders}

The analytical starting point is social situations, or - as it is sometimes called - an actorin-situation complex. This is the place in which the social order is 'refracted'; it is undoubtedly constructed, but this process, as I contend, shows a few universal properties which cannot be treated as glosses of the actualised components of macro-structure. The intercourse of individuals is regulated, and mutual responses as well as alternative expectancies are harmonised in the course of constructing social orders that determine actors' conduct. The substantive relevance of the interaction domain consists in the social location of individuals: they are physically present at a given place and time, but this presence is somehow structured. 'Situatedness' means that individuals are somewhat committed, involved or engaged in interaction, that they are not only present but also have some reasons to stay with one another. The range of this commitment is 'standardised'; it is an element of individual socialisation equipment that is available in the form of gestures, social habits, and types of communication with members of one's social setting. In the course of interaction, it deals with the co-ordination of actions regardless of whether they are intentional or undesigned. The consensus is elaborated in the interplay of cognitions, emotions, and modes or, finally, in the very tendency to co-operate - an effort of co-ordination that is taken by the actors. On the one hand, every situation is temporary and provisional; on the other hand, it can be replicated if interaction rituals are produced, ensuring continuity and meaningfulness in human activities. There are many interaction orders which are not a simple function of actors' acquired experiences, but the feature of meaningful relationships between what is acquired and what is the lived, 'here-and-now' of occurring events. The relationships can be moulded both with the aid of social (generalised) classifications and by means of applying unique (particular) descriptive categories. Thus, interaction rituals are not a direct expression of social structures. They are that which is revealed as an expression oriented toward those expectations 'from above'.

Exploiting the findings of Erving Goffman [1963, 1967/1982, 1974/1975, 1983] and Randall Collins [1981, 1987, 1998: 20], I treat the encounter as the basic analytical category. This reality returns periodically and is constituted around the negotiation and exchange of resources. Following Collins, I assume that two basic kinds of resources should be taken into account: a) cultural capital conceived as stored remembrances of previous interactions, vocal styles, types of knowledge etc., and b) emotional energy in reference to the level and type of effect experienced by individuals in a given situation. Also important is the distinction between generalised capital, which is available as impersonal symbols related (in a generalised way) to knowledge, position, authority, and group, and particularised capital, which deals with concrete individual remembrances of one's own features and the features of other specific persons. Interaction among people consists in conversa- 
tion, in the course of which actors particularly invest their own cultural capital and emotional energy to gain the maximum possible payoff, for example in the form of specific group membership. What is important for me is to trace the process of achievement of group inclusion, the characteristic properties of levels of inequality in actors' resources, and the ways of consensus elaboration.

\section{The Anti-utopia of Transcendental Delirium}

The plot of the novel Moscow-Pietushki starts in Moscow, when the main character, 'Eternal' Vienitchka, arrives at Kursk Railroad Station. Led by angels, he is visiting places located en route where alcohol is sold. A small suitcase held to his chest - or rather the suitcase's contents - confirms that he is going to visit Pietushki to see his girlfriend. Presents and alcohol are the two precious goods that his suitcase contains. Entry into the train signifies the rapid acceleration of activity as the result of establishing contacts with other passengers, which is facilitated by the ubiquitous presence of alcohol. The trip between the two title railroad stations is a structural occasion or opportunity to carry on a 'parlour game', the stuff of which is the habitus of the Soviet male. At the same time, the parlour game, though it is sustained by means of props of systemic provenience, is ruled by its own laws, which are autonomous in relation to 'sober' or official Soviet reality. Alexander Zinoviev [1984: 36] aptly observes that drunkenness in Russia is "[...] a genuine national religion". The characters that appear on the pages of the novel are typical believers of this religion who, with the aid of alcohol, inaugurate and maintain a short-lived world of delirious anti-utopia. The novel discloses basic ways of adaptation and survival in the predefined paramount reality, not only through participation in rituals imposed 'from above', but especially through the construction of sub-universes (or micro-worlds) which are located on the edge of the architectonics of the system. Those interim enclaves are islands of exterior life within the system reality.

Interaction rituals used by Vienitchka are a kind of social adjustment that is not a common escape into alcoholism, a Mertonian 'retreatism' to the empire world, but is something of an innovation, a processing of the symbolic world of the empire into a carnival performance. The interaction scenario is a promise to access the charms of transcendental delirium (a world of anti-utopia) in which any rules of 'really existing socialism' are no longer in force. The only structural obstacle is the lack or temporary insufficiency of alcohol that is conceived as a constitutive precondition to initiate the alternative reality of delirious and semi-delirious states. What seems to be important in Vienitchka's confessions is the recipe to 'soften' (or 'dilute') the empire edifice. The architectonics of the empire predefine all social reality: beginning with the symbols of a class which fights for liberation, the pantheon of saints of communism and the iron laws of Marxism-Leninism, the ways of labour organisation and celebration, and finally the accustomed savoir-vivre under 'really existing socialism'. If this arrangement were treated statically, in orthodox Homo sovieticus terms, any endeavours to domesticate the empire would be impossible as the orbits of actors' actions would be exactly calculated and would fulfill the expectations of communist demiurges. However, the real orbits of actors' actions have a bizarre tendency towards perturbation, which can only be explained by the circumstance that those planned, 'from above' courses of actors' actions do not predict their intersection. If the 
train on which Vienitchka travelled were a perfect reflection of the ideological structure of class formations, all passengers would take their seats supplied with tickets legitimating their ride, or more broadly - they would engage in appropriate interactions and get off the train at the proper railroad stations. Moreover, this originally unfocused interaction set cannot be ordered according to the systemic scenario, which would attract, like a magnet, actors to their places and induce them to play the roles of meek passengers.

The kingdom of randomness enters into the forefront. It is a kingdom in which the iron laws of social formations are presented as corroded leftovers encountered in the course of a struggle with a hiccup. This kind of turbulence resists any mathematics. Post-apocalyptic delirium requires special competencies that are released by the inseparable application of Kantian an sich and für sich: "And you will convince yourselves that it [hiccup] will start within an hour. When you hiccup for the first time you will be surprised at its suddenness and unexpectedness; then you will be surprised at the irreversibility of the second, third, and next hiccups" (MP: 45). The way to understand the hiccup, its unexpected beginning and equally surprising end, is the recognition of the almighty hand of God and the powerlessness of the actor. "We are flimsy worms, while it is ubiquitous. It, or the hand of God, is raised above all of us, in the face of which only fools and bastards do not wish to humiliate themselves. Reason is not able to comprehend Him, and therefore He is" (MP: 46). But this proof that God exists is at the same time an enrichment of the competencies of the actor, a change of particularised cultural capital. The hiccup of a man reconciled with the demands of non-communist transcendence becomes a rightful and self-evident component of rituals that are in force within the transcendental delirium sphere. It is not a faux pas. It is what is in terms of situation the social expectancy of the interaction participants, and what at the same time is surprising in the moments of their coming and going.

The subsequent events also disclose other details that can be treated as empirical replicas of the universal logic of interaction episodes. The way in which the interaction among passengers is initiated is characteristic. Each of them is interested in the maximisation of payoffs in cultural capital and the currency of emotional energy. Going by train creates this kind of occasion because the actors dispose of various resources that can be trumps in the process of the negotiation of group inclusion. The emotional attractiveness of Vienitchka is so high that it can be expected that it will inevitably attract the other passengers. But the statement that the attractiveness is constituted by the very fact of possessing huge alcohol resources would be a grave simplification. If it were so, the empire itself, as an independent alcohol monopolist, would be most attractive in the sense of delivering positive emotional energy. But the empire rather resembles a capricious fig tree, or a producer of bottlenecks of accessibility. The recognition of this is a social fact in the Durkheimian sense. Individual memory includes sufficiently numerous remembrances determined by the cadences of opening and closing liquor shops and joints, and the accessibility and inaccessibility of various brands of alcoholic fluids. What becomes important is the actor's proper planning of a delivery trajectory, as well as the skill to refine the stateowned selection by preparing mixtures and through the observance of consumption sequence. "And now, let us think of what I could create out of the shit that still remains in my suitcase?" - Vienitchka asks himself (MP: 50). The ability to make alcohol bouquets and the art of their consumption are a condition, the fulfillment of which creates the chance for a conversation. Possessing alcohol is a determinant of the actor's status, certifying that he/she is sufficiently intelligent, or that he/she can also provide other resources 
that are worth negotiating for. The basic resource is usually social attractiveness, that is, an ability to carry on an interesting talk and share with the partner or partners the knowledge of how that attractiveness can be achieved or organised. The actor in the transcendental delirium sub-universe is a bricoleur in the midst of other bricoleurs, free riders produced by the system but also sufficiently autonomous to create their own situations. The mutual evaluation is the contribution of actors to initiating reciprocally profitable interaction. And it is not a zero-sum game: greater interaction competence on the part of the actor, as is the case of Yerofeyev, does not generate exploitative relationships.

A cybernetic control hierarchy determines the flows of information and energy in particular interaction episodes. Owing to this, Vienitchka is not a monopolist but, as a sophisticated heavy drinker, must seek energetic support, not only in alcohol, but also in other, less sophisticated or competent, interaction participants. Grandfather Mitrych and his grandson are looking after Vienitchka, and Vienitchka himself is required to search for an audience in which he has to play his prescribed role. Actors emit signals, unintentionally or knowingly, which certify their statuses. However, the statuses are not related to their age, income, social origin and race, as in normal sociological reality, but to alcohol and the parlour game resources which actors possess or aspire to possess. Vienitchka, as a possessor of these resources, is an object of desire for physiologically and interactionally starved lovers of alcohol and other people's properties. Hence Vienitchka's going out onto the car platform is a trigger for interaction and induces the Mitrychs' to penetrate the contents of his luggage. In this phase of interaction, Vienitchka is not looking to resemble his bricoleurs. The risk accompanying such an alternative initiation of interaction would be much more than in the case of the Vienitchka-Mitrychs interaction because it would require a greater investment of cultural capital and emotional energy from Vienitchka and his potential partner. That the Mitrytchs lick their lips, if we completely exclude incredible calculation or a genetic defect, is a visible symptom of their interest in entering into the interaction, even at the cost of an accusation of theft and drinking someone else's property. In the case of sophisticated bricoleurs such visible and legible symptoms of interest in contact either do not occur or they can provide a given person with an incentive to spend on adequately high investments into the process of the initiation of interaction.

From this moment, the plot gains a livelier tempo. Vienitchka not only scolds the Mitrychs, but also offers them to drink up the next fifty grams of alcohol to fix the thread of interaction bound in this way. This outwardly insignificant fifty grams is, in this moment, a crucial element in the definition of the situation, because it is a signal for other passengers who resemble Vienitchka that it is worthwhile investing their own resources. As young Mitrych croaks, a young man with a black moustache appears, whose entry indicates not only the cunningness of his visage but also the aristocratism of the owners of resources. "I suppose you won't decline mine, hmm?" (MP: 54) - this is the best possible legitimisation of the status of a newcomer. The interaction becomes irrevocably ritualised, the world is divided into - as Pierre Bourdieu would call it - those who are above and those who are below. But the occupation of the lower position does not mean a total degradation: even drinking from a mug brought out from between womb and diaphragm is done by craning one's neck as pianists do. To recapitulate: every interaction participant can find within the interaction a specific place in relation to the resources he/she possesses, and can play a role that consolidates the order, which is regenerated in the cycle of alcoholic toasts and incessant conversation. 
It should be stressed that the constituted interaction order requires the persistent defining elements of the actor. The first danger is Amorac in the gabardine coat, silent until now and listening to the conversation between Vienitchka and the black-moustached man. Amorac, later nicknamed 'Decembrist', marks his participation by thwarting participants' expectations. The name of Alexander Hertzen is a word-detonator. The incorrectness of Amorac-Decembrist's reaction has two principal aspects. The first is an attempt at untitled intrusion into a conversational space without the previous declaration of readiness to offer resources. The second consists in an attempt to confuse two orders: the systemic and the interactional. Introducing some threads of the empire architectonics into the discourse dealing with the ontology of transcendental delirium is a common gaffe, which is the result of officiousness or rather a lack of sufficient competencies which would make a proper interpretation of the situation possible. Participation in interaction requires proper distance to the played role, or silence if one is not asked for one's opinion. Disobedience of these rules shows at the same time how strong group solidarity is, and how firm the membership of participants playing prescribed roles is. The short emotional explosion of the group, visible at least in the juicy response "Leave him alone, you fucking Decembrist!" (MP: 57), simultaneously pacifies Amorac-Decembrist, shows him his position in the interaction as a person who needs educational endeavours, and as a result increases the general level of positive emotional energy: "And all of us, all of a sudden and imperceptibly, have started to be tipsy; cheerfully and imperceptibly, imperceptibly and lewdly" (MP: 57). The group not only passes on the first designs of its disintegration by Amorac, it also comes out of this event strengthened. Nevertheless, Amorac also achieves success, because in the light of the previous ordering of the interaction space he could only succeed in this way and eventually gain group membership. The role of 'whipping boy' has been the only structural possibility produced by the interaction order. Increased social density, to formulate it in strict sociological language, increases the likelihood that human individuals will enter into interaction, even under conditions of inequality.

Constructing the metaphysics of transcendental delirium necessitates confronting aporias, which, even if they are overcome on the spot, inevitably lead to disintegration. The first problem is the way in which teetotalers can be qualified. The scholastics of the blackmoustached man's argumentation break down when somebody discloses that Goethe was a teetotaler. Fortunately, the scholastics of Vienitchka are sufficiently powerful to prevent this interpretative discrepancy in the doctrine. The doctrine proves its effectiveness after the recognition that Goethe's temperance was a symptom of latent and deep alcoholism, which was compelling him to teetotalism-suicide and to force the heroes of his works to drink. The second problem deals with the relationship between the ticket inspector and passengers. The ontology of the system is substituted with an analogous ritual of alcoholkilometres. The ritual, in comparison with its systemic archetype, is much more flexible in application. Since none of the 'normal' passengers has a ticket, he/she may take out the right to ride when he/she offers the proper - in relation to the number of kilometres amount of alcohol, or when he/she is able to use other resources, namely some substitutes capable of satisfying the expectations of the ticket inspector. The palette of possible payoffs is broad, and determined by the passengers' resources: from punching a passenger in the face, to standard amounts of alcohol, and stories that hit upon the emotional expectancies of the ticket controller. Vienitchka, as a component of the particular cultural capital of the ticket inspector, is defined as a deliverer of over-eroticised world history. 
A special category of experiences included in the structurations that fix the stream of alcohol-laden courses of action is determined by the virtual or factual presence of women. One thing is common: the 'flapper' disturbs the idyll of delirious or semi-delirious states, is a structural inconsistency written in the world of transcendental delirium, and is a particularisation of a cultural resource which 'pushes' actors out of the area constituted by purely alcohol-driven expectancies. The first type is the woman as a transcendental value, an object that is both present as the leitmotif of Vienitchka's ride and absent or unavailable in concrete actions. The second type is the woman as an intervening variable, or more strongly: the woman who destroys the seemingly irrefutable universality of alcohol lemma, visualised in the form of a curve connecting the points of falling asleep and being roused from crapulence. "The lemma is universal until a flapper is not present" (MP: 61), the black-moustached man concludes. To paraphrase Gorky's famous maxim: one could say that the proof of any interaction in the world of transcendental delirium is the way in which women are treated. Although their presence is a source of structural discontinuity, they are functionally and interactionally indispensable. Women represent the gate to the system reality, buying back bottles and selling alcohol. They are anti-delirious revivers in situations of excessive sinking in the alternative world of alcohol banquets, but dialectically they also create situations in the sense that they induce the initiation of delirious interactions again. The third type is the representative of the empire. When such a woman becomes an interpretation dominant, the interactional anti-world of abstinence is established. It is an authentic Sovietisation of consciousness, the reshaping of an actor in the form of Homo simplex, pulled by the structural constraints of the empire. The functional equivalent of Miss sovieticus is a common prostitute or whore (the fourth type of woman), who 'uncorks' the actor's consciousness, as de-fetished goddesses of the empire. The system, as the woman, is powerful only as transcendence, and grows weaker when it is an element of 'full-blooded' interactions. The fifth type is the woman as a hybrid of masculinised femininity. Hybrids of this kind usually appear as the next actors entering into the interaction. "Appetising figures grow as eating proceeds", says Decembrist (MP: 67). They emit signals in the form of the lack of fore-teeth, the menopause moustache, and physical and emotional scars. On the one hand, women of this kind are sufficiently masculinised, that is, adequately drunk and non-erotic. On the other hand, they introduce a real threat to the interaction order when they emit particular layers of femininity, which demolishes the convention of drunken conversation. The sixth type is the woman in the dark, loving and suffering, an enclave of soberness and normality.

The interactional presence of virtual or imagined entities is nothing unusual in the world of transcendental delirium. The emergence of 'bloodless' actors is a function of the cultural capital possessed by the 'real' actor. The stock of cultural capital is determined by the level of the ability to construct an imaginative sphere of interaction. This experiential synthesis is also subject to ritualisation: the moments of initiation of such interaction and its course are not random. Angels are the actors who legitimate the correct course of 'real' interactions. They are equipped with instruments of symbolic violence and use them as a resource, and obtain in exchange subordination, confirming their high position in the relation network. The angels are inverted reflections of luminaries of the system. They do not offer only charms of pure transcendence; if it were so their attractiveness would be equal to the solemn prattle of Bolshevik ideologists. The angels are shields that disperse the "normality' of the empire and produce an interaction superstructure, owing to which the actu- 
ality of the socialist habitus is presented as unattractive or deprived of resources which are worth negotiating for. Satan is presented as a structuralised remorse of conscience, a tempter pacified by the simple exorcism of shame. The sphinx then symbolises the end of Vienitchka's efforts to arrive at Pietushki, it appears inevitably as a signal of the end of a series of interactions, the exhaustion of resources, and traffic-jams within channels of conversation. The effects of this interactional gallopade are the fast consumption of resources and the dispersion of the trajectories of particular actors. The involvement of actors within the interaction reaches its turning point, and its maintenance is gradually weakened along with the burning out of the potential of emergency definitions of the action situation. It is a structural property, written in the scenario of the temporality of the transcendental delirium world, as an in-between world that is located on the borderlines of the empire. Each of the actors, literally or virtually, in turn falls out of the train, lands back in the grip of the empire, but he/she is equipped with new components of cultural capital drawn from the just completed encounter. This means that the delirious interaction ritual will be resumed when a structural possibility for its enactment occurs. However, the particular components of the actors' cultural capital, not the paroxysm of the empire, are what motivate them.

The jaws of the empire Leviathan, which produce macro-structural framings for the activities of the actors, are still open, and this property is no paroxysm but is an immanent feature of the system. If the jaws were closed, the black-moustached lemma would cease to be in force, it would give way to the Homo sovieticus lemma, and the socialisation intestines of Leviathan would spit out only normative puppets of the system. The sub-universe of transcendental delirium is a reality placed 'between' what flows into the open jaws of Leviathan and what its guts are, which function as a factory for brainwashing and programming system automatons. Involvement in the reality of this sub-universe is a collective levitation, which makes it possible both to perceive the system interior from the removed observer's point of view and to be exposed to the reflexes of the external world, whether in the form of the 'friendly' periphery of the 'people's' democracy countries or in the form of the 'corruption' of the West. The levitational character of the transcendental delirium sub-universe means also its chronic makeshiftness and short-livedness: the logic of bricoleurs and the logic of the exhaustion of resources.

\section{Final Remarks}

It would be premature to formulate far-reaching conclusions on the basis of the analysis of a single case. I was aiming at a specification of typical features of Soviet man and the ways in which he/she has moulded his/her relations with the environment. A theoretical aspect of my own analysis was the implementation of universal instruments of social interaction analysis in reference to the Moscow-Pietushki piece. This made it possible to grasp a few puzzling regularities.

The centre of gravity of my analysis was the relationship sets that connected the individual and the empire. I was stressing that, in spite of the overwhelming pressure of structural factors, the Soviet social actor, as a theoretical construct, remains a basic agency force. This is possible because Soviet reality - whether on the analytical level or the factual one - does not determine in toto the activities of Soviet social actors. It generates, of course, impassable framings for actors' activities, imposes official interaction rituals, and 
forces out testimony of loyalty to the system, but it shows its helplessness on the unofficial level. The actors are able to realise, within a limited range, their own purpose if they encrust their activities as 'quotations' taken from official reality, do not openly profane a corpus of systemic sacrum, or do not play the roles of its apostles. There is a certain kind of gentleman's agreement that determines the rules of the social game, including a permissible margin of freedom. Thus the system generates some emergency-valves, starting with the selection of alcoholic liquors and the ways of acquiring them, and ending with the construction of an alternative and short-lived reality of transcendental delirium. And dialectically, if such mechanisms actually are in force, they increase the autonomy of the actors.

If the hierarchic-nomenclature organisation of society is a normal element of the official reality of the system, then the hierarchy of actors as providers of desired resources within the transcendental delirium world becomes the equivalent of the former. The precondition for achieving the latter is an initial egalitarianism among alcohol consumers, which 'levels' the official social hierarchy. The actors' acceptance of that initial egalitarianism is an essential ritual of the passage from the official reality to the alternative one. The characters of Yerofeyev's novel, who aspire to participate in the world of delirium, leave their ordinary roles on the platform of the railway station, but also take them when getting off the train. None of the actors participating in the collective levitation withdraws permanently from the official reality. At the same time, he/she temporarily suspends being the Soviet man and remains yet the Soviet man. He/she does not become a rebel or contestant but is a bricoleur among other bricoleurs who are responsible for the course of alternative interaction. $\mathrm{He} / \mathrm{she}$ knows that an alcohol-interaction order is only a moment in the face of the supposed eternity of the system. But he/she also remembers (which is a component of both generalised and particularised cultural capital) that the empire exists as long as the trains run, or, more precisely, until the empire generates structural opportunities of passage to the alternative world of delirium. An infringement of the equilibrium is simply unprofitable, an example of this being the prohibition practices introduced by Mikhail Gorbachev in 1985: perhaps, in contrary to the expectations of sovietologists, the Soviet empire collapsed because a of violation of the unwritten 'social contract' and not because of the second socialist revolution introduced 'from above', as Tatyana Zaslavskaya [1990] claims.

The last statement can support the formulation of more general statements that refer not only to the specificities of the Soviet empire but also homologically to other types of empire. The statement, that every empire if it wants to survive and reproduce the social order must generate structural opportunities of 'internal' alternative worlds, still needs to be verified in other empirical replicas. Any such research programme, in which this statement would be a heuristic principle, should embrace not only 'documents' dealing with the centre of the Soviet empire, but also 'evidence' referring to its periphery - countries formerly called 'people's democracies'. Studying Soviet society with the aid of 'documents' dealing with social life reveals defense mechanisms generated by the system [Mokrzycki 2001: 106-108]. 'Really existing' Soviet socialism, as a unique solution in the spheres of economy, culture and social relations, was a true centre, radiating outward in the organisation of social life in the peripheral countries. Studying the processes characteristic of the Soviet Union is thus a necessary condition for understanding analogous processes occurring in the 'friendly' peripheries of a people's democracy. A description of the transcendental delirium phenomenon should find and characterise its functional equivalents (e.g. the ways alcohol softens the system) and then trace whether they are still essential com- 
ponents of the habits of the citizens in CEE countries. In this way the thesis on the macrosocial consequences of 'really existing socialism' can be partially corroborated or refuted. In turn, it would be possible to apply theoretical findings to characterise different empire types and make a comparison of the practices of the empire man with the activities of the contemporary, Western and CEE bourgeois.

AleKSANDER MANTERYs is an associate professor in the Institute of Philosophy and Sociology of the Polish Academy of Sciences. He has published two books: Multiple Realities in Social Theories (in Polish, Warsaw 1997) and The Classical Idea of the Definition of the Situation (in Polish, Warsaw 2000; English edition forthcoming) and a dozen papers dealing with social theory (in English and Polish). He is now working on the book Social Situations Theory.

\section{References}

Alexander, Jeffrey C. 1992. The Promise of a Cultural Sociology: Technological Discourse and the Sacred and Profane Information Machine. Pp. 293-323 in Richard Münch and Neil Smelser, eds., Theory of Culture. Berkeley: University of California Press.

Alexander, Jeffrey C. \& Philip Smith 1993. "The Discourse of American Civil Society: A New Agenda for Cultural Studies.” Theory and Society, Vol. 22, pp. 151-207.

Blumer, Herbert 1969/1986. Symbolic Interactionism: Perspective and Method. Berkeley: University of California Press.

Calhoun, Craig 1995. Critical Social Theory. Oxford: Basil Blackwell.

Collins, Randall 1981. "The Microfoundations of Macrosociology.” Pp. 261-293 in Sociology Since Midcentury: Essays in Theory Cumulation. New York: Academic Press.

Collins, Randall 1987. "Interaction Ritual Chains, Power and Property: The Micro-Macro Connection as an Empirically Based Theoretical Problem.” Pp. 193-206 in Jeffrey C. Alexander, Bernhard Giesen, Richard Münch \& Neil J. Smelser, eds., The Micro-Macro Link. Berkeley: University of California Press.

Collins, Randall 1995. "Prediction in Macrosociology: The Case of the Soviet Collapse." American Journal of Sociology, Vol. 100, pp. 1552-1593.

Collins, Randall 1998. The Sociology of Philosophies: A Global Theory of Intellectual Change. Cambridge, Mass. and London: The Belknap Press of Harvard University Press.

Denzin, Norman K. 1987. The Alcoholic Self. Beverly Hills, California: Sage Publications.

Denzin, Norman K. 1989. Interpretive Interactionism. Newbury Park, California: Sage Publications.

Denzin, Norman K. 1992, Symbolic Interactionism and Cultural Studies: The Politics of Interpretation. Oxford and Cambridge, Mass.: Blackwell.

Denzin, Norman K. 1994. "The Art and Politics of Interpretation.” Pp. 500-515 in Norman K. Denzin \& Yvonna S. Lincoln, eds., Handbook of Qualitative Research. Thousand Oaks: Sage Publications.

Goffman, Erving 1963. Behavior in Public Places: Notes on the Social Organization of Gatherings. New York: The Free Press.

Goffman, Erving 1967/1982. Interaction Ritual: Essays on Face-to-Face Behavior. New York: Pantheon Books.

Goffman, Erving 1974/1975. Frame Analysis: An Essay on the Organization of Experience. Harmondsworth: Penguin Books. 
Goffman, Erving 1983. “The Interaction Order.” American Sociological Review, Vol. 48, No. 1 (February), pp. 1-17.

Kane, Anne E. 1996. "The Centrality of Culture in Social Theory: Fundamental Clues from Weber and Durkheim.” Pp. 161-180 in Stephen P. Turner, ed., Social Theory and Sociology: The Classics and Beyond. Cambridge, Mass. and Oxford: Blackwell Publishers.

Mokrzycki, Edmund 2001. Bilans niesentymentalny [Non-sentimental Balance]. Warsaw: Wydawnictwo IFiS PAN.

Rambo, Eric, Elaine Chan 1990. "Text, Structure and Action in Cultural Sociology.” Theory and Society, Vol. 19, pp. 635-648.

Sewell, William H., Jr. 1992. "A Theory of Structure: Duality, Agency, and Transformation.” American Journal of Sociology, Vol. 98, pp. 1-29.

Sheff, Thomas J. 1997. Emotions, the Social Bond, and Human Reality: Part/Whole Analysis. Cambridge, UK: Cambridge University Press.

Skocpol, Theda 1973. States and Social Revolution: A Comparative Analysis of France, Russia, and China. New York: Cambridge University Press.

Smith, Philip 1998. The New American Cultural Sociology. Cambridge: Cambridge University Press.

Sommers, Margaret R. \& Gloria D. Gibson 1994. "Reclaiming the Epistemological 'Other': Narrative and the Constitution of Identity.” Pp. 37-99 in Craig Calhoun, ed., Social Theory and the Politics of Identity. Malden, Mass.: Blackwell Publishers.

Staniszkis, Jadwiga 1992. The Ontology of Socialism. Oxford: Clarendon Press.

Sztompka, Piotr 1993. The Sociology of Social Change. Oxford and Cambridge, Mass.: Blackwell.

Sztompka, Piotr 1999. Trust: A Sociological Theory. Cambridge: Cambridge University Press.

Tilly, Charles 1993. European Revolutions, 1492-1992. Oxford and Cambridge, Mass.: Blackwell.

Wallerstein, Immanuel. 1974, 1980, 1989. The Modern World System. 3 vols. New York: Academic Press.

Wright, Erik Olin 1997. Class Counts: Comparative Studies in Class Analysis. Cambridge: Cambridge University Press.

Yerofeyev, Venedikt 1994. Moskwa - Pietuszki [Moscow-Pietushki]. Trans. Andrzej Drawicz. Wrocław: Wydawnictwo Dolnośląskie.

Wiley, Norbert 2000. "Movies and the Mind: A Pragmatist Approach.” International Journal for Germanic Linguistics and Semiotic Analysis, Vol. 5, No. 1 (Spring), pp. 93-126.

Zaslavskaya, Tatyana 1990. The Second Socialist Revolution: An Alternative Soviet Strategy. Trans. Susan M. Davies \& Jerry Warren. London: I. B. Tauris.

Zinoviev, Alexander 1984. Rosja i Zachód [We and the West]. Trans. N.B. and J.G. Warsaw: Wydawnictwo "Krąg".

Zinoviev, Alexander 1986. Apologia praktycznego rozumu [Apology of Practical Reason]. Trans. Jan Wit. Warsaw: Wydawnictwo "Wola". 